\title{
Monetarizing the social value: theory and evidence
}

\author{
José-Luis Retolaza, Leire San-Jose and Maite Ruiz- \\ Roqueñi
}

\section{ABSTRACT}

Over the last decade important efforts were made to integrate economic and social value in organizations within a unic report. This is significant because it reflects greater interest and demands in society concerning not just economic but social responsibilities of organizations.

However, social organizations are finding problems to give value to their social contribution, mainly due to the prominence of financial economic indicators; which curiously only have instrumental value in this type of entities.

The aim of this paper is to develop a social accounting model that allows incorporating the social value, in its monetized form, employing accounting standards; with the economic one. It is not possible to monetize full social value with this model, although it does show economic value with social impact, socio-economic return and specific social value.

Application of this model makes possible the quantitative and monetized comparison of integrated value between companies, which would involve more efficient decision-making based on symmetry and more complete information (private organizations), more efficiency in consumption or investment decisions (private individuals) and efficient indicators for establishing public policies (public administration). Overall, it could prove to be a basic and valuable component of business reputation.

KEYWORDS: Social accounting, sostenibility, shared-value, stakeholder theory, finance.

ECONLIT DESCRIPTORS: M140, P130, Q130.

Reference: RETOLAZA, J.L., SAN-JOSE, L. \& RUIZ-ROQUEÑI, M. (2015): "Monetarizing the social value: theory and evidence", CIRIEC-España, Revista de Economía Pública, Social y Cooperativa, 83, 43-62.

Correspondence: Jose-Luis Retolaza, Senior Research at Deusto Business School, Bilbao. Email: joseluis.retolaza@ deusto.es; Leire San-Jose, Associate Professor and Director of ECRI [Ethics in Finance \& Governance/Stakeholders] at the University of the Basque Country (UPV/EHU), Bilbao. Visiting Research Fellow at University of Huddersfield, UK. Email: leire.sanjose@ehu.eus; Maite Ruiz-Roqueñi, Associate Professor and member of ECRI at the UPV/EHU, Bilbao, Director of AURKILAN. Email: maite.ruiz@ehu.eus. 


\section{Monetizando el valor social: teoría y evidencia}

RESUMEN: Durante la última década se han hecho esfuerzos importantes para integrar en un único informe el valor económico y social de las organizaciones. Esto es significativo porque refleja un mayor interés y mayores demandas de la sociedad; y no sólo en relación con las responsabilidades económicas de las organizaciones, sino también sociales.

Sin embargo, las organizaciones Sociales encuentran problemas para poner en valor su contribución social, debida sobre todo a la prominencia de los indicadores económicos financieros; los cuales curiosamente solo tienen un valor instrumental en este tipo de entidades.

El objetivo de este trabajo es desarrollar un modelo de contabilidad social que permita incorporar el valor social, en su forma monetizada, empleando las normas de contabilidad; con la económica. No es posible monetizar el valor social completo con este modelo, aunque sí muestra el valor económico con impacto social, la rentabilidad socio-económica y el valor social específico.

La aplicación de este modelo hace posible la comparación cuantitativa y monetizada del valor integrado entre las empresas, lo que implicaría una eficiente toma de decisiones basada en la simetría y en la información más completa (organizaciones privadas), una mayor eficiencia en las decisiones de consumo o de inversión (particulares) e indicadores eficaces para el establecimiento de políticas públicas (administración pública). En general, podría consolidarse como un componente básico y valioso de la reputación empresarial.

PALABRAS CLAVE: Contabilidad Social, Sostenibilidad, valor compartido, teoría de stakeholder, finanzas.

\section{Monétisation de la valeur sociale : théorie et évidence}

RÉSUMÉ : Au cours de dix dernières années, des efforts conséquents ont été déployés pour intégrer dans un rapport unique la valeur économique et sociale des organisations. II s'agit d'un point significatif car cela reflète un plus grand intérêt et des demandes supérieures de la société, pas uniquement en ce qui concerne les responsabilités économiques des organisations, mais également en ce qui concerne leur responsabilité sociale.

Cependant, les organisations sociales rencontrent des difficultés pour mettre en valeur leur contribution sociale, dues principalement à la prépondérance des indicateurs économiques financiers. Étrangement, ces derniers n'ont en effet qu'une valeur instrumentale pour ce type d'entités.

Ce document a pour objectif le développement d'un modèle de comptabilité sociale permettant d'incorporer la valeur sociale, sous sa forme monétisée et en utilisant les normes de comptabilité, à la valeur économique. II est impossible de monétiser la valeur sociale complète avec ce modèle, bien qu'il montre la valeur économique avec l'impact social, la rentabilité socio-économique et la valeur sociale spécifique.

L'application de ce modèle rend possible la comparaison quantitative et monétisée de la valeur intégrée entre les entreprises. Cela impliquerait une prise de décision efficace fondée sur la symétrie, l'exhaustivité des informations (organisations privées), une meilleure efficacité concernant les décisions de consommation ou d'investissement (particuliers) et des indicateurs efficaces pour l'établissement de politiques publiques (administration publique). De manière générale, ce modèle pourrait s'établir comme composant basique et indispensable pour la réputation des entreprises.

MOTS CLÉ : Comptabilité sociale, pérennité, valeur partagée, théorie des stakeholders, finances. 


\section{1.- Introduction*}

It has been widely acknowledged that social performance is an important value for society (Wood, 1991; Porter \& Kramer, 2011), as the sustainability and social results of companies are valuable for all stakeholders, which includes shareholders, but also society and environment (Freeman, 1984). Some initiatives are widely recognized: the Global Reporting Initiative (GRI), for instance, and Social Return on Investment (SROI) highlight the importance of assessing social impact on organizations. They are, altogether, excellent initiatives. But unfortunately the GRI does not permit a full comparison between companies because the proxies used to measure social value are flexible, differ from firm to firm, and GRI indicators are not totally fixed. So, the GRI provides a similar structure for measuring social value but not in quantitative comparable terms. In this regard, the SROI is efficient only for valuing investment projects adopted in a company; then help improving the future social investment decision, but is not efficient for analysing social return for the company, or at least not where total operational returns are concerned in the past.

To measure the social value it is necessary back to the theory of the firm. In this regards, the problematic concerns the lack of integration between the economic and the social views, and one understanding of this is offered by the theory of separation (i.e. Friedman, 1962). In this theory, ethics (understood as the social function of the enterprise) and financial performance are two different independent aspects, as the foundation of the company lies in economic and not in social achievements. Other authors, including Freeman (1984) criticizes this view and advocate a complete integration of the economic and social aspects of organizations. Under this parameter, it becomes necessary to develop a way to measure economic value, and this has already been done. Indeed, much time and effort went into economic undertaking, and the results have been totally accepted. In our view, however, social value is also important. The concept of social value has been the object of research for a long time within the economic sciences (Schumpeter, 1909; Tool, 1977). To date there is a lack of social measurement standardization (Wood \& Leighton, 2010).

Consequently, in this paper, a methodology is developed for monetizing social value, taking as read that comparability is only achieved if the social value measurement model can be analysed along with the economic model. Basing our work on the widely used and accepted model in organizations, a model is produced to monetarize social development. To do so it was necessary to translate the social value indicators into financial parameters.

\footnotetext{
* The authors are grateful to reviewers and editor of CIRIEC. This work is part of the research group ECRI "Ethics in Finance and Social Value" (GIU12_58) and it is supported by the UPV/EHU research project (EHUA 12/04), UFI11/51 and FESIDE.
} 
Accordingly, an analysis of secondary data is carried out for the financial literature, and a workshop study and 28 interviews with corporate social responsibility director of Spanish Ibex-35 companies during 2013-2014 are conducted to determine the monetizable social value aspects, indicators and proxies that determine social impact relating to different stakeholders. In addition, a two-stage concept analysis was used: firstly, the process is described, and then the indicators and the proxies are shown using two cases, these being a nonprofit organization and a public agency.

In brief, this paper is driven by the motivation to develop a methodology for monetizing social performance, in order to extend economic value to encompass social value, rather than develop an independent model for economic value to measure social performance. The paper has as its objective the development of a methodology that enables the integration of social with economic value. This study aims to cover the gap in the literature using the criterion of monetization to develop a comparable social performance methodology where social value is measured utilizing economic rules. One reason why this will prove difficult is to be found in the different perspectives between the economic and the social, and because some social aspects are impossible to monetize. This is why the methodology developed in this study does not completely measure the full social value ${ }^{1}$ created by organizations but, following Clark et al. (2004), will make comparability possible between different types of organizations: commercial, social, governmental and others.

The remainder of this paper is organized as follows. First, a review of the contributions in terms of the theories is carried out to explain the firm view in which developed methodology is based on. In section 3 the methodological aspects are detailed: action research as methodology; phenomenological perspective as a mechanism for identifying the variables; stakeholder theory as an explanatory framework; the cost-benefit analysis as tools for arguing the methodology; and fuzzy sets and the polyhedral view as the paradigm that makes it possible to understand the results and engage in future applied research lines. Following social polyhedral value methodology for stakeholders is developed and it is shown six-step process to monetize the social value and the three level social value methodology -economic value with social impact, socio-economic return and specific social value. The next section 5, using two examples has described how use this methodology. Finally, Section 6 offers the main conclusions, limitations and future lines of research. 


\section{2.- Theoretical foundation}

Since the beginning of the industrial age, the company has been considered as an economic generating entity (Groth et al., 1996), its social function being relegated to the background (Friedman, 1962; Fernandes et al., 2011). To simplify, the company can be said to be an entity dedicated to generating optimal and efficient products and services for society, and increasing their value. Thus, the only indicator that shows the achievements of society is company profit. It is assumed that if the company achieves economic benefit, this will impact positively on society, thereby fulfilling the aim of business and society. In this regard, the first economist approach adopted in modern economics (i.e. Adam Smith, 1776) postulated that the only values considered were economic values, since the social was considered as an extension, through the distribution of economic value (Friedman, 1962). In consequence, organizations have been endowed with sophisticated and efficient accounting systems based on reasonable value to try to identify and convey an accurate picture of the company, referring only to its economic function value (Gassenheimer et al., 1998).

The debate around the integration of economic and social value starts with Bowen (1953), who emphasized the social common in relation to organizations. The theoretical foundation comes from works by Preston \& Post (1975) and Freeman (1984); and Carroll (1979) and Aupperle (1984) contribute to methodologies for integrating the social and economic view. The most commonly defended arguments (Friedman vs. Freeman) are grounded in the shareholder-based theory of the firm, in which the economic value perspective is found only in the value created by the company for shareholders. The most popular argument is that capital is the main element in business management; and, rooted in the assumed risk of shareholders, the principal value indicator is that of Earnings after Interest and Taxes. Meanwhile, other perspectives argue for a broader value, and the Ontological Stakeholder Theory falls into this category (Wood, 1991; Mitnick, 1994; 2000; Retolaza \& San-Jose, 2011; San-Jose \& Retolaza, 2012; Retolaza et al., 2014), as the theory of the firm is explained from a global perspective in which value is understood as a whole. The argument is simple: if business risks affect the whole set of stakeholders it seems legitimate to show which of the values generated correspond to the particular stakeholders involved, including the shareholders. Even where it the case that each stakeholder could assess their own risk-benefit matrix, it would be reasonable for some of those involved, such as the Public Administration and, either directly or through it, the citizens as well, to positively value the overall integrated balance of the value creation or destruction in each organization (Olsen \& Nicholls, 2005). This would be the optimal quantification.

The integration of social and economic values in a single report is not direct but progressive, so to understand their evolution, after reviewing the proposals of Frederick (1994) and Wood (2010), we detected four major steps that were needed to understand the cognitive stages of social value. In the 
first stage, the company is understood as an open system that interacts with the environment and society (Boulding, 1956), but more importantly with responsibility for creating a social common (Bowen, 1953). In the second step, this idea is stipulated both in terms of theoretical (Preston \& Post, 1975; Freeman, 1984) and methodological foundations (Carrol, 1979; Aupperle, 1984). In the third phase, the 1990s are characterized, on the one hand, by attempts to apply academic development to business management (Freeman et al., 2008), and, on the other hand, by a proliferation of empirical studies that contribute to corporate social performance (i.e. Orlitzky et al. 2003; Margolis et al. 2007). In the fourth stage, from the beginning of the second decade of this century, the Structural-Ontological view is developed (Wood, 1991; Mitnick, 1994; 2000; Retolaza \& San-Jose, 2011; San-Jose \& Retolaza, 2012), and this provides the foundations of the polyhedral view developed in this paper.

\section{3.- Methodology specifications}

Many methodologies set out to determine the social value of organizations based on previous works by Tuan (2008), Olsen \& Galimidi (2008), Wood \& Leighton (2010) and Mulgan (2010). To develop the conceptual model, a two-stage concept analysis was applied. Firstly, it explained the perspectives that underpin the model, and secondly the methodology on which the model is based to carry out its application. In a following section, the indicators and proxies are shown using some companies as possibility exemplification.

This is followed by an explanation of the perspectives for understanding the view used to develop the methodology in its first stage: Action Research relates to the research process; stakeholder theory to an understanding of the firm; and phenomenological analysis and fuzzy sets relate to knowledge, the former to knowledge per se, and the latter to metric form.

Action Research: the methodology used for the development of the research is "action research" (Lewin, 1946; Reason \& Bradbury, 2007), characterized by two aspects. First, it involves external and internal experts working jointly to analyse the research problem; and, second, "action research" suggests a continuous and circular process, with four consecutive phases: identification of the problem; participatory analysis; proposal of solutions; and outcome assessment and the identification of new problems. This cycle is continuous, in order to bring about constant improvement. One advantage is that performing action research is the same as performing an experiment. It is an empirical process. This research method can enable the integration of professional and academics to develop the social value (Barraket \& Yousefpour, 2014) that integrates the experience of the company and experience of the conceptual value model. 
Stakeholder Theory: the stakeholder theory (Freeman, 1984; Freeman et al., 2008; 2010) is a theoretical rationale that allows the company to be understood in a different way; concretely, in terms of the interests of those involved, who affect and are affected by the company, because it is they who really contribute value and are, in turn, rewarded with it. The underpinning of this theory makes it possible to specify value interests within a limited and accessible set of stakeholders. This theoretical grounding enables the identification and systematization of genuine interests, so that the social value of the people involved can be qualitatively and quantitatively defined (Sherrouse, Semmens \& Clement, 2014). There are some doubts as to the utilization of this theory as a basis for developing a social value model; from a critical perspective, the supposed social value remains limited to the interest of the people participating in a particular organization, whose interests might be in conflict with those of other organizations; likewise, it might be the case that a broad number of people are excluded from the supposed social value generated, those who are termed non-stakeholders². Without wishing to minimize the problems raised and the practical impact they might bring, and taking into account that they suggest future research lines with great potential, the fact is that the first problem is substantially reduced if we focus on a diverse plurality of values instead of concentrating only on financial interests (Argandoña, 2011). With regard to the exclusion of the interests of non-stakeholders, if we broaden the stakeholder concept not only to those involved in value generation, but also to those affected by risk, and even extend it in terms of sectors to non-stakeholders ${ }^{3}$, it becomes possible to approach an inductive conceptualization of social value.

Phenomenological Perspective: Following the phenomenological approach in the epistemological line adopted by Husserl (1859-1938), we consider that social value cannot be defined in a single way, but rather that it concerns the set of expectations and interests of the stakeholders involved (Tarde, 1902). With this point of departure, using the classical Husserlian "epoché" (1907), we will not hold value to be defined by the organization's objectives, but by the perception that the recipients (the stakeholders) have concerning the value that such actions produce (Polkinghorne, 1989). At a future date it would be necessary to ascertain whether there is or is not correspondence between the value sought by the organization and the value perceived by its stakeholders. This is not however the object of this work.

Fuzzy logic: Fuzzy sets were introduced by Zadeh (1965), but they were transferred to business management aspects by Kaufmann \& Gil Aluja (1986). Classical sets are assumed not to be the only option, and indeed a group of possibilities that are not fixed or closed provide a solution for integrating results, although in some cases it is necessary to accept ranges or approximations in order to come up with operational decisions. Each organization is a different reality, where the set of stakeholders creates a specific ecosystem for the generation and distribution of value (economic, social and emotional) (Freeman, 1984; Freeman et al., 2010; Retolaza \& San-Jose, 2011). In this connection, it has been

2.- This might be the case with financial exclusion, food exclusion or a lack of access to medicines. Similarly, excessive impact due to the centrality of the organization as a social agent might bring about the alienation of the State's responsibility in the interests of lobbies.

3.- Such would be the case of vehicle insurance in Spain where, if no company wishes to have you as a client (stakeholder), a body exists at a sectoral level that will act as the policy holder. This mechanism for sectorally integrating non-stakeholders may be useful for other kinds of exclusion, such as in financial or health terms. 
assumed that single value is subjective and inadequate (Jensen, 2001), which means the range of the value is necessary along with the approximations from different points of view. The global social value perspectives are achieved only if the stakeholders' perceptions and interests are analysed and integrated or, in their absence, are submitted as a fuzzy set composed of the different objectifications of the value generated.

Cost-Benefit Analysis: We will evaluate the model by analysing social value with the help of a cost-benefit analysis (Mishan, 2007; Prest \& Turvey, 1965). Cost-benefit analysis methodology, widely used in analyses in which outputs are not directly monetary, aims to transform the value of these outputs into monetary units, and establish a relationship between the efficiency of required inputs and outputs. Two main lines of analysis are applied, depending on the objectives and divisibility of the factors involved: the first involves reducing inputs, the second, maximizing outputs. This analysis has become widespread because it is easy to use, and estimates and compares the equivalent money value for the community of benefits and costs of projects, decisions or organizations, in order to establish whether they are worthwhile. It is therefore a useful analysis for social value 4 , including the evaluation of public good (Gravela, Michelangelib \& Trannoy, 2006), social preferences (Murphy \& Ackermann, 2014), vulnerable children's programmes (Vallejos et al., 2013), environmental and ecosystem evaluation (Sherrouse, Semmens \& Clement, 2014) and social enterprises (Barraket \& Yousefpour, 2014), but in the methodology developed in this paper the orientation is toward output maximization.

Polyhedral View: there is a diversity of stakeholders in companies, and stakeholders which influence and are influenced by the company have different interests (Freeman, 1984, Freeman et al., 2010). So, the polyhedral view shows the different values that each of the interest groups might give to the organization. Depending on those interests, they will give more or less value to the organization (Argandoña, 2011). Accordingly, the assessment is complex because we have to become acquainted with the actual interests of the stakeholders, which is what the value depends on.

\section{4.- Social polyhedral value methodology}

The methodology proposed utilizes different outputs from an organization to which social value can be attributed, although these may depend upon who is doing the evaluation and what their interests are. The principal problem of this approach resides in the difficulty of generating a single value, as, depending on the prism -stakeholders- from which the valuation is made, certain particular outputs

4.- Some social value measures have used the Social Value Chain (Olson \& Grimaldi, 2008) to develop the measurement model for establishing the social value of organizations. 
may, or may not, be considered as social value, for that particular group. This means that the same project, firm or organization may produce a different social value, according to the particular identity of the stakeholder carrying out the analysis. From a classical perspective, in which a single objective value is supposed to exist, determination of the value is not simple. From the fuzzy perspective (Zadeh, 1965; Kaufman \& Gil-Aluja, 1986), we are able to show the whole social value created for the different stakeholders. Thereby, attainment of the single or total value would be limited to the consolidated and not the sum value.

In this sense, having explained the perspectives and methodologies in which the methodology is established, we have developed the social polyhedral value methodology for stakeholders, which provide the solution to the problem of single value. This model is grounded firstly in the stakeholder theory, which understands the company to be a whole that has social responsibilities to stakeholders and, sometimes; secondly, it employs a phenomenological perspective, which does not use objects as essential elements of reality, but phenomena; and the third tool is fuzzy logic, due to the possibilities that variability and flexibility offer to clusters which, in consequence, cause the social value of firms to vary (see Figure 1).

\section{Figure 1. SPOLY. Polyhedral View}

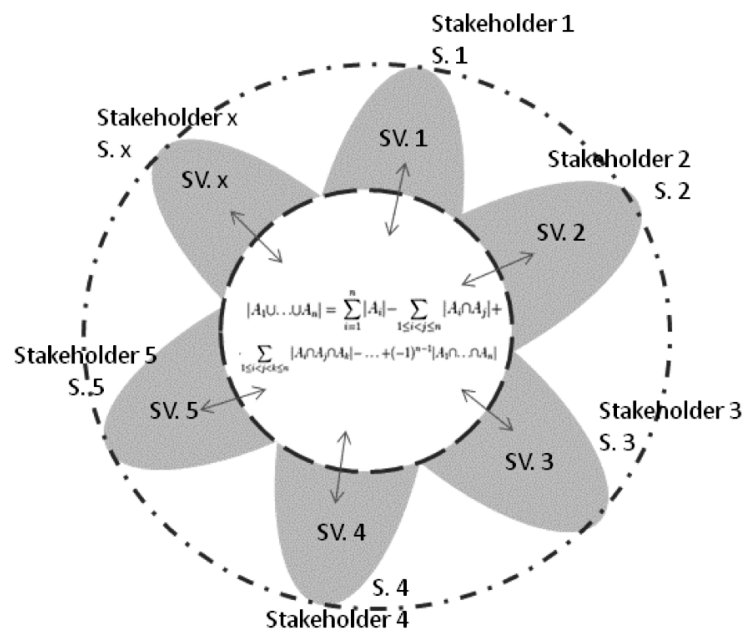

SOURCE: Retolaza, San-Jose \& Ruiz-Roqueñi, 2015.

This stakeholder-centred approach makes it possible to solve the usual problem affecting analyses with a socio-economic impact, which only tend to take into consideration tangible costs, ignoring other kinds of impacts associated with various interest groups or stakeholders (Emerson et al., 2000). However, if one wished to apply the model from the customary premises of Stakeholder Theory 
(Freeman, 1984; Freeman et al., 2008; 2010), a biunivocal relation should be assumed to exist between stakeholders and interests, which does not have to occur in all cases, because within the same interest group diverse and even conflicting interests converge. Therefore, different interest groups share interests and one single stakeholder may have different interests (Retolaza \& San-Jose, 2011), which complicates and even makes impossible the application of the methodology through traditional stakeholder theory. Then, the ontological stakeholder theory is the basic of this methodology and the more unification of interests the more common interests among stakeholders and less individual what reduced the complexity into the measurement of the social value. However, this polyhedral view could vary during the time and depend on the stakeholders of the company.

Basing our approach on analyses with academic and professional experts (three workshops and 28 interviews during 2013 and 2014), and following experience with various firms that have applied it, it was determined that the methodology requires six successive steps (see Figure 2). In first place, through the strategic design of the organization, fundamentally comprising the mission, vision and values and the key interest groups, the stakeholders that the organization intends to have a social impact on are identified. The result of this first step concludes with the stakeholder map. Below, we identify the aspects (value variables) in which these stakeholders perceive that the organization generates (or destroys) value for them; this is done through in-depth interviews with the stakeholders themselves. In this way, a matrix of interests is produced with the stakeholders and the interests they have indicated. Later this is transformed into a matrix termed an Ecosystem of Interest. Then, the proxies that best fit and facilitate monetary quantification of the value generated for each value variable are identified, and algorithms are established that enable consolidation of the joint value of the different proxies identified. Thus, the qualitative model of analysis is created. The fourth step consists of the attribution of quantitative value to the proxies, for which the approach of reasonable value is employed, applying market prices, public reference prices, or estimated value based on related data. In the fifth step, calculations are made for each of the poles of interest, and the outcomes are then consolidated, and also holistically interpreted, the result being a Social Value Report. Lastly, as would be expected in a process of action research, feedback takes place between the outcomes obtained and the actual social approaches of the organization, facilitating an improvement in or rethinking of its social value methodology. 


\section{Figure 2. Process of Social Value Methodology}

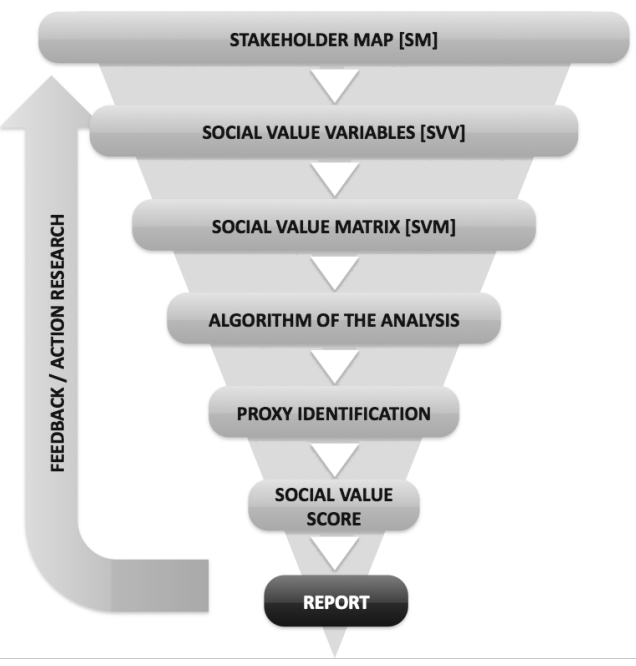

Where the determinant variables are concerned, there are no fixed variables for all organizations because they will depend on the different existing stakeholders, on their interests, and on the value variables perceived by them. Nonetheless, the methods will determine the variables in each organization in a standardized way and, in consequence, will be analysable and comparable. The conclusions obtained by Wood \& Leighton (2010) are therefore supported, in that the social value measurement must be underpinned by three principles: proportionality, comparability and standardization.

\section{5.- Two case studies of monetizing social value}

Social value is divided into three levels using evaluation criteria: the first is economic value generation with social impact; the second, the socio-economic return generated; while the third is the specific social value generated. 


\subsection{The generation of economic value with social impact}

The first of the quantifications, generation of economic value with social impact, is analysed following the assumption that the existence of firms is justified through the social value they generate. It is, of course, supposed that this is why the obtaining of a margin between costs and income is possible; additionally, with no need for its function to be fundamental, indirect social value is produced through diverse outputs, such as the payment of salaries, the collection of value-added tax, or taxes on results. The Global Reporting Initiative (GRI) considers that the best way of calculating the social impact of economic activity is the Cash Value Added Statement, since it is the best indicator for reflecting the degree of the entity's commitment to its respective stakeholders. The AECA (Spanish Association of Accounting and Business Administration), however, is of the opinion that value added acts as a more suitable indicator, for two fundamental reasons: on one hand, it better captures the real contribution of value by the company; on the other, it enables, in a simpler way, the integration of outcomes in specific geographical, national or sectorial areas.

In this connection, fuzzy logic makes it possible to argue for the potentiality of values in ranges in comparison with the single value in such a way that, although both indicators are deemed to be suitable, they can complement one another. This proposal consists of using the Cash Value Added Statement when dealing with a micro-analysis relating to the calculation of the value of an economic unit, as it better reflects the generation and global distribution of the value captured, though not necessarily added, by the firm. However, when the analysis is sectorial, typological, geographical, or of any other kind, Value Added would work better as a reference, because the Cash Value Added Statement might provide the illusion of a wider perspective of the value generated.

The next table (Table 1), following the indications not only of the GRI but also of the AECA, presents the variables that comprise economic value with social impact. It must be borne in mind that the transformation of the Cash Value Added Statement into Value Added comes about by replacing income in the Economic Value Generated column with Value Added. Likewise, operating expenses are subtracted from the Economic Value Distributed. In addition, added to the suppliers is what we have termed payment of own capital to suppliers, which consists of the variation in the price of the stockmarket value, the reasoning behind this being that this corresponds to a form of remuneration at least as important as the distribution of dividends or an increase in carrying value. That is why it must be included. 


\section{Table 1. Variables and Description of Economic Value with Social impact}

\begin{tabular}{|c|c|c|}
\hline & VARIABLES & DESCRIPTION \\
\hline $\begin{array}{l}\text { ECONOMIC } \\
\text { VALUE } \\
\text { GENERATED }\end{array}$ & Income & $\begin{array}{l}\text { Net sales + income from financial } \\
\text { investments and asset sales }\end{array}$ \\
\hline \multirow{6}{*}{$\begin{array}{l}\text { ECONOMIC } \\
\text { VALUE } \\
\text { DISTRIBUTED }\end{array}$} & Operating expenses & $\begin{array}{l}\text { Payments to suppliers + non-strategic } \\
\text { investments + payment facilities }\end{array}$ \\
\hline & Wages and employee benefits & Total of monetary flows aimed at workers \\
\hline & Payments of external capital to suppliers & Payments to suppliers of financial services \\
\hline & $\begin{array}{l}\text { Expenditure and investment with a } \\
\text { social aim }\end{array}$ & $\begin{array}{l}\text { Voluntary contributions and investment } \\
\text { for social improvement }\end{array}$ \\
\hline & Payment of own capital to suppliers & $\begin{array}{l}\text { Dividends + increase in reserve funds } \\
\text { Variation in the price of the stock-market value }\end{array}$ \\
\hline & Payments to the Administration & VAT + Company Tax + Other Taxes \\
\hline
\end{tabular}

Adapted from the GRI, 2006 and 2013; and from AECA 2002.

Adoption of this modelling allows us to make standard calculations for the economic value captured by an organization and its ensuing distribution among the different social agents (socialization).

\subsection{Socio-Economic Return}

This aspect of social value consists of the socio-economic environment that exists between the body in question and the Administration. Fundamentally, to calculate this return the methodology of cost-benefit analysis is applied, subtracting from the results generated in relation to the Administration whatever costs the latter has incurred vis-à-vis the entity under analysis. It must be noted that in the case of the socio-economic return, we are dealing, within the framework of the Polyhedral View, with a particular instance of value generation for a specific stakeholder, the Administration. It is possible to fall into a reductionist approach and consider Company and Administration to be comparable, in that the latter is chosen by the former and supposedly manages its interests; nevertheless, as the capacity of the Administration to meet all the needs and interests of the company is limited, the return value produced will always be lower than the social value generated for the various social groups of interest taken together. The following table (Table 2) defines the variables taken into account for the calculation procedure. 


\section{Table 2. Variables and Description of the Socio-Economic Return}

\begin{tabular}{|c|c|c|}
\hline & VARIABLES & DESCRIPTION \\
\hline \multirow{3}{*}{$\begin{array}{l}\text { ECONOMIC } \\
\text { VALUE } \\
\text { DISTRIBUTED } \\
\text { TO THE } \\
\text { ADMINISTRATION }\end{array}$} & Payments to the Administration & VAT + Company Tax + Other Taxes \\
\hline & $\begin{array}{l}\text { Savings by the Administration } \\
\text { (non-assumption of services) }\end{array}$ & $\begin{array}{l}\text { Cutting expenditure that the Administration would be } \\
\text { obliged to incur if the entity did not exist / ceased to exist }\end{array}$ \\
\hline & $\begin{array}{l}\text { Savings by the Administration in } \\
\text { outsourcing }\end{array}$ & $\begin{array}{l}\text { Differential in the input / output relation contracted with } \\
\text { the entity, with regard to the second highest bid }\end{array}$ \\
\hline \multirow{4}{*}{$\begin{array}{l}\text { ECONOMIC } \\
\text { VALUE } \\
\text { CONTRIBUTED } \\
\text { BY THE } \\
\text { ADMINISTRATION }\end{array}$} & Subsidies & $\begin{array}{l}\text { Contributions that the Administration pays the entity } \\
\text { for diverse concepts }\end{array}$ \\
\hline & Additional costs in contracting & $\begin{array}{l}\text { Increase in the cost for a service / product contracted } \\
\text { with regard to the best tender }\end{array}$ \\
\hline & Negative externalities present & $\begin{array}{l}\text { Expenditure the Administration is obliged to incur for } \\
\text { actions of the organization in the current financial year }\end{array}$ \\
\hline & $\begin{array}{l}\text { Anticipation of future negative } \\
\text { externalities }\end{array}$ & $\begin{array}{l}\text { Pro rata advance of future costs put to tender by } \\
\text { current actions of the organization }\end{array}$ \\
\hline
\end{tabular}

\subsection{Specific social value}

Specific social value is understood to be the non-economic value that the organization distributes among its several interest groups. The fundamental characteristic of this value is that it can only be appreciated as such by a specific group, while the value it contributes to other specific interest groups is much lower or even zero. The other fundamental aspect is its non- monetary nature, which makes us resort to proxies of a subjective kind to monetarize it. This perspective of social value, which is quantitatively and monetarily measurable via proxies, requires a dual explanation: on the one hand, a synthetic analysis of the process of identification, quantification and monetarization; and, on the other, of the itemized variables and proxies that will evidently depend upon the company or organization in which we are measuring. For this reason we only set out the case of two firms, one private nonprofit, the other public, in order to demonstrate its application and use.

Below we present two cases: Lantegi Batuak ${ }^{5}$ and Viviendas Municipales de Bilbao ${ }^{6}$. In the following table (Table 3) the main characteristics of each of the analyses can be seen, with their similitude and divergences.

5. - Lantegi Batuak was created in 1966 and is a non-profit organization that creates job opportunities that are as standardized as possible in order to achieve the maximum development of persons with disabilities, particularly of an intellectual kind and with preference given to residents in Bizkaia. It had nearly 3000 employees during 2013 and is located in the Basque Country (Spain).

6.- Viviendas Municipales de Bilbao is a public body, attached to Bilbao City Council, that was created in 1918, its purpose being to provide the inhabitants of Bilbao with housing; its own funds add up to more than 160 million Euros and its assets amount to more than $4.000 \mathrm{dwellings.}$ 


\section{Table 3. Specific Social Value Matrix}

\begin{tabular}{|c|c|c|c|}
\hline \multicolumn{4}{|c|}{ Lantegi Batuak } \\
\hline STAKEHOLDER & VALUE VARIABLES & PROXIES & RELATIONAL ALGORITHMS \\
\hline \multirow[t]{7}{*}{ FAMILIES } & Net wages & $\Sigma$ net wages & \\
\hline & Opportunity Cost & $\begin{array}{l}\Sigma \text { working hours * half hour's } \\
\text { wage for working women * \% } \\
\text { female employment rate }\end{array}$ & \multirow{6}{*}{$\begin{array}{l}\Sigma \text { (wages; opportunity cost; } \\
\text { savings on food; } \\
\text { savings on health; } \\
\text { job support; R\&D\&i; transport) }\end{array}$} \\
\hline & Savings on food & $\begin{array}{l}n^{0} \text { pax * expenditure per } \\
\text { day on food * no. days }\end{array}$ & \\
\hline & Savings on health & $\Sigma$ Health expenditure & \\
\hline & Job support & $\Sigma$ (hours devoted ${ }^{*}$ cost); expenditure & \\
\hline & R\&D\&I & $\Sigma$ expenditure & \\
\hline & Transport & $\Sigma$ subsidized expenditure & \\
\hline THIRD SECTOR & $\begin{array}{l}\text { Purchases from Third } \\
\text { Sector entities } \\
\text { Positive externalities }\end{array}$ & $\begin{array}{l}\text { \% average value added suppliers* } \\
\text { total purchase volume } \\
\Sigma \text { expenditure on open projects }\end{array}$ & $\begin{array}{l}\Sigma \text { (3rd. sector purchases; } \\
\text { externalities expenditure) }\end{array}$ \\
\hline \multicolumn{4}{|c|}{ Viviendas Municipales de Bilbao } \\
\hline STAKEHOLDER & VALUE VARIABLES & PROXIES & RELATIONAL ALGORITHMS \\
\hline USERS & $\begin{array}{l}\text { Weighted savings on rent } \\
\text { Special levies }\end{array}$ & $\begin{array}{l}\text { (Market rent -real rent) }{ }^{*} \\
\text { income ratio * no. family members } \\
\Sigma \text { expenditure on special levies }\end{array}$ & $\begin{array}{l}\Sigma \text { Weighted savings on rent } \\
+ \text { special levies }\end{array}$ \\
\hline NEIGHBOURS & $\begin{array}{l}\text { Social dynamization } \\
\text { Urban dynamization }\end{array}$ & $\begin{array}{l}\text { Savings on rents * Social rootedness } \\
\Sigma \text { (special levies; Programmes; } \\
\text { urban development expenditure) }\end{array}$ & $\begin{array}{l}\text { Value of social dynamization * } \\
\text { Urban development expenditure }\end{array}$ \\
\hline CITIZENS & $\begin{array}{l}\text { Solidarity } \\
\text { Economic return }\end{array}$ & $\begin{array}{l}\text { Savings on rents * Risk of exclusion } \\
\text { Average savings on rent * } \\
\text { no. occupied flats }\end{array}$ & $\begin{array}{l}\text { Average savings * } \\
\text { occupied flats * } \\
\text { Risk of exclusion }\end{array}$ \\
\hline $\begin{array}{l}\text { ENTITIES IN THE } \\
\text { SECTOR }\end{array}$ & Externalities & $\Sigma$ Cost of externalities & $\Sigma$ Costs of externalities \\
\hline
\end{tabular}

Both matrices show parallels in the categorizations that are deduced from the Polyhedral View. However, both the stakeholders and the value variables identified, and consequently the proxies and algorithms of integration, are different. So all the analyses share the structure of analysis, but diverge in the elements of valuation. The more similar are two organizations, in terms of their mission, social aim and their stakeholders, the more similar will be the specific matrix of value; the more the entities diverge, the greater will be the distance between their Specific Social Value matrices. 


\section{6.- Concluding remarks}

This paper has shown a monetized social measurement methodology that overcomes the obstacles that impede the integration of social and economic value and prevent their comparability, and also makes homogenization possible, not only in mercantile, but also in social and third sector organizations. The methodology constitutes a contribution to the academic and professional debate around the integration of economic and social value, because the social polyhedral value methodology for stakeholders, is a model that permits the comparability and standardization of social value, regardless of the type or form of an organization. It is founded in the ontological stakeholder view and is considered a measure for economic evaluation. This first contribution lies in the perspectives the model stands on, which make it methodologically robust.

Furthermore, this methodology integrates and makes possible the quantification and monetization of economic value with social impact, socio-economic return and specific social value. The first two are common to every company, but the third aspect depends on stakeholder interests because it is able to resolve the different potential values that represent the interest of each stakeholder that assumed risk in the company. Accordingly, case analyses were used to show the reliability and validity of the process when applied, respectively, to a private nonprofit and a public organization. Despite the difficulties involved, this social value measurement methodology opens the way for standardization.

In sum, this article's reformulation of the social value measurement methodology has several implications. Social and economic responsibility rests with financial managers, so the role of social responsibility merges with the economic function, representing a convergent inclusion of these two concepts. As the methodology is based on financial rules, integration between social and economic values does not depend on operational barriers. The comparability of companies in terms of social creation is something that society demands, and it is made possible with this methodology through information asymmetry and standardization. The government could take it into consideration for future decisions, including those that concern productivity and excellence.

The approach proposed in this paper centres on organizations, and takes stakeholders as the unit of analysis, which allows for an individualized approach to a changing reality defined intersubjectively by all stakeholders over time. However, there are at least two limitations. In first place, the methodology developed does not value all the social value created because of the impossibility of monetizing some of the values. Secondly, the objectification and weighting of social value, as in traditional accounting, requires some international standardized rules, which do not as yet exist. The development of social accounting is undoubtedly the main future research line. 


\section{References}

ARGANDONA, A. (2011): Stakeholder theory and value creation, Working Paper IESE No. 9, IESE Business School, Barcelona, Spain.

Asociación Española de Contabilidad y Administración de Empresas (AECA) (2002): Indicadores para la gestión empresarial, Working Paper n 17, AECA Press, Madrid, Spain. Retrieved 15 April, 2013 from http://www.aeca.es/comisiones/comisionpg.htm.

AUPPERLE, K.E. (1984): "An empirical measure of corporate social orientation”. In: L. El. Preston (Ed.), Research in corporate social performance and policy, Greenwich, CT: JAI Press, vol. 6, 27-54.

BARRAKET, J. \& YOUSEFPOUR, N. (2014): "Evaluation and social impact measurement amongst small to medium social enterprises: process, purpose and value", Australian Journal of Public Administration, 72(4), 447-458.

BOWEN, H.R. (1953): Social Responsibilities of the Businessman-Toward an Understanding of the Ethics and Economics of Society, New York: Harper.

BOULDING, K.E. (1956): "General systems theory: the skeleton of science", Management Science, 2, 197-208.

CARROLL, A.B. (1979): "A three-dimensional conceptual model of corporate social performance", Academy of Management Review, 4, 497-505.

CLARK, C., ROSENZWEIG, W., LONG, D. \& OLSEN, S. (2004): Double bottom line project report: Assessing social impact in double bottom line ventures, Columbia Business School, Retrieved 10 April, 2014 from http://www.riseproject.org/DBL_Methods_Catalog.pdf.

EMERSON, J., WACHOWITZ, J. \& CHUN, S. (2000): "Social return on investment: exploring aspects of value creation in the nonprofit sector". In: The Robert Enterprise Development Fund, Chapter 8, 131-173. Retrieved November 1, 2013 from http://www.redf.com.

FERNANDES, P., ROCHA, J. \& RODRIGUES, F. (2011): "The complete ethics chain of value: from social and ethical principles to the role of the official auditing and accounting revision entities", International Journal of Management and Enterprise Development, 10(2), 216-231.

FREDERICK, W.C. (1994): "1978 Classic Paper: From CSR1 to CSR2: The maturing of business and society thought", Business \& Society, 33, 150-164.

FREEMAN, R.E. (1984): Strategic management: A Stakeholder Approach, Boston, U.S.: Pitman.

FREEMAN, R.E., HARRISON, J.S., WICKS, A.C., PARMAR, B.L. \& DE COLLE, S. (2010): Stakeholder theory: The state of the art, Cambridge, UK: Cambridge University Press. 
FREEMAN, R.E., HARRISON, J.S. \& WICKS, A. (2008): Managing for Stakeholders: Survival, Reputation and Success, New Haven, Conn: Yale University Press.

FRIEDMAN, M. (1962): Capitalism and freedom, Chicago, U.S: University of Chicago Press.

GASSENHEIMER, J.B., HOUSTON, F.S. \& DAVIS, J.C. (1998): "The role of economic value, social value, and perceptions of fairness in interorganizational relationship retention decisions", Journal of the Academy of Marketing Science, 26, 322-337.

GLOBAL REPORTING INITIATIVE (GRI) (2006): Guía para la elaboración de memorias de sosteniblidad. Versión 3.0., Paper retrieved 10 February, 2014 from https://www.globalreporting.org/resourcelibrary/Spanish-FSSS-G3-complete.pdf.

GLOBAL REPORTING INITIATIVE (GRI) (2013): G4 Sustainability Reporting Guidelines, Paper retrieved 10 February, 2014 from https://www.globalreporting.org/resourcelibrary/GRIG4-Part1Reporting-Principles-and-Standard-Disclosures.pdf.

GRAVELA, N., MICHELANGELIB, A. \& TRANNOY, A. (2006): "Measuring the social value of local public goods: an empirical analysis within Paris metropolitan area", Applied Economics, 38, 1945-1961.

GROTH, J.C., BYERS, S.S. \& BOGERT, J.C. (1996): "Capital, economic returns and the creation of value", Management Decision, 24(6), 21-30.

HUSSERL, E. (1907): Die Idee der Phanomenologie. Fünf Vorlesungen, Hua Il'. Traducción al español: Edmund Husserl, La idea de la fenomenología. Cinco lecciones, F.C.E., México, Madrid, Buenos Aires, 1982.

JENSEN, M.C. (2001): "Value Maximization, Stakeholder Theory, and the Corporate Objective Function", European Financial Management, 7, 297-317.

KAUFMANN, A. \& GIL ALUJA, J. (1986): Introducción de la teoría de los subconjuntos borrosos a la gestión de las empresas, Santiago de Compostela, Spain: Milladoiro.

LEWIN, K. (1946): "Action research and minority problems", Journal of Social Issues, 2(4), 34-46.

MARGOLIS, J.D., ELFENBEIN, H.A. \& WALSH, J.P. (2007): Does it pay to be good? A meta-analysis and redirection of research on the relationship between corporate social and financial performance, Working Paper No. XX, Cambridge, MA: Harvard Business School.

MISHAN, Q. (2007): Cost Benefit Analysis, $5^{\text {th }}$ ed. New York, U.S: Routledge.

MITNICK, B.M. (1994): "Systematics and CSP: The theory and processes of normative referencing", Business \& Society, 34, 5-33.

MITNICK, B.M. (2000): "Commitment, Revelation, and the Testaments of Belief: The Metrics of Measurement of Corporate Social Performance", Business \& Society, 39(4), 419-465.

MULGAN, G. (2010): "Measuring Social Value", Stanford Social Innovation Review, 8(3), 38-43. 
MURPHY, R.O. \& ACKERMANN, K.A. (2014): "Social Value Orientation: Theoretical and Measurement Issues in the Study of Social Preference", Personality and Social Psychology Review, 18(1), 1341.

OLSEN, S. \& GALIMIDI, B. (2008): Catalog of approaches to Impact Measurement: Assessing Social Impact in Private Ventures, The Rockefeller Foundation.

OLSEN, S. \& NICHOLLS, J. (2005): A Framework for Approaches to SROI. DRAFT for Haas Social Metrics Conference Reviewers, Working Paper, Country: City Berkeley. Retrieved May 10, 2013 from

http://www.haas.berkeley.edu/responsiblebusiness/conference/documents/SROIFrameworkv.Ha as.pdfSaraOlsen.pdf.

ORLITZKY, M., SCHMIDT, F.L. \& RYNES, S.L. (2003): "Corporate Social and Financial Performance: A Meta-analysis", Organization Studies, 24(3), 403-441.

POLKINGHORNE, D.E. (1989): "Phenomenological research methods". In: R.S. Valle and S. Halling (Eds.). (1989), Existential-phenomenological perspectives in psychology: Exploring the breadth of human experience, New York, U.S: Plenum Press.

PORTER, M.E. \& KRAMER, M.R. (2011): "Creating Shared Value”, Harvard Business Review, 4, 113.

PREST, A.R. \& TURVEY, R. (1965): “Cost Benefit Analysis: A Survey”, The Economic Journal, 75(300), 683-735.

PRESTON, L.E. \& POST, J.E. (1975): Private Management and Public Policy: The Principle of Public Responsibility, Englewood Cliffs, NJ: U.S. Prentice-Hall.

REASON, P. \& BRADBURY, H. (Ed.) (2007): Handbook of Action Research, 2nd ed. London: England: Sage.

RETOLAZA, J.L. \& SAN-JOSE, L. (2011): "Social economy and stakeholder theory, an integrative framework for socialization of the capitalism", CIRIEC-España, Revista de Economía Pública, Social y Cooperativa, 73, 193-213.

RETOLAZA, J.L., SAN-JOSE, L. \& RUIZ-ROQUEÑI, M. (2014): "Ontological Stakeholder View: An Innovative Proposition", Global Business Review, 15(1), 25-36.

RETOLAZA, J.L., SAN-JOSE, L. \& RUIZ-ROQUEÑI, M. (2015): Social Accounting for Sustainability: Monetizing the Social Value, Berlin Heidelberg: Springer.

RUIZ-ROQUEÑI, M. \& RETOLAZA, J.L. (2012): "Stakeholder Marketing: A New Orientation in the Discipline and Practice of Marketing", Journal of Modern Accounting and Auditing, 8(6), 811-826.

SAN-JOSE, L. \& RETOLAZA, J.L. (2012): "Participation of stakeholders in corporate governance: foundation ontological and methodological proposal", Universitas Psychologica, 11(2), 619-628. 
SCHUMPETER, J. (1909): "On the Concept of Social Value", The Quarterly Journal of Economics, 23(2), 213-232.

SHERROUSE, B.C., SEMMENS, D.J. \& CLEMENT, J.M. (2014): "An application of Social Values for Ecosystem Services (SolVES) to three national forests in Colorado and Wyoming", Ecological Indicators, 36, 68-79.

SMITH, A. (1776): The Wealth of Nations. Edited by Edwin Cannan, 1904. Reprinted New York: Modern Library, 1937.

TARDE, G. (1902): Psichologie economique, Paris, France: Féliz Alcan.

TOOL, M.R. (1977): "A social Value Theory in Neoinstitutional Economics", Journal of Economic Issues, 11(4), 823-846.

TUAN, M. (2008): Measuring and/or estimating Social Value Creation: Insights into eight integrated cost approaches, Working Paper 12/15/08, Bill and Melinda Gates Foundation University Press. Retrieved 16 April, 2014 from https://docs.gatesfoundation.org/Documents/wwl-reportmeasuring-estimating-social-value-creation.pdf.

VALLEJOS, C., REVECO, R., BACHELET, V.C., GOYENECHEA, M., VELASQUEZ, M., DE LA PUENTE, C., BUSTOS, L. \& ZAROR, C. (2013): "Cost-effectiveness evaluation of social value of an intervention program in a vulnerable child population, lag or deficit in integral development chile 2012", Value In Health, 16(7), 710.

WOOD, C. \& LEIGHTON, D. (2010): Measuring social value the gap between policy and practice, London: UK. Demos Press.

WOOD, D.J. (1991): "Corporate Social performance Revisited”, The Academy of Management Review, 16(4), 691-718.

WOOD, D.J. (2010): "Measuring corporate Social Performance: A Review", International Journal of Management Reviews, 12(1), 50-84.

ZADEH, L.A. (1965): "Fuzzy Sets", Information Control, 8, 338-353. 